\title{
IMPACT OF BROWN ALGAE SUPPLEMENTATION IN DRINKING WATER ON GROWTH PERFORMANCE AND INTESTINE HISTOLOGICAL CHANGES OF BROILER CHICKS
}

\author{
Manal K. Abou El-naga ${ }^{1}$ and M.M. Megahed ${ }^{2}$ \\ ${ }^{I}$ Department of Poultry and Fish Production, Faculty of Agriculture, Minoufia University, \\ Minoufia, Egypt \\ ${ }^{2}$ Department of Avian and Rabbit Medicine, Faculty of Veterinary, Zagazig University, Egypt.
}

(Received 3/6/2018, accepted 15/7 /2018)

\section{SUMMARY}

$\mathrm{L}$ imited research suggests the effect of brown seaweed in animal nutrition for improving gut health and performance, but there isn't any research suggests the effect of oral liquid seaweeds brown algae in broiler nutrition. So, this study was aimed to evaluate the effect of liquid brown seaweed algae (Ascophyllum nodosum) supplementation on broiler chick's performance and their intestine histology. The experimental chicks (total number of 120, one - day old, Indian River chicks) were used and fed the same diets during the experimental period (1-35 days). Brown seaweed algae were added in fresh water at the concentrations of 0 and $1 \mathrm{ml} /$ liter fresh water. Results indicated that chicks received $1 \mathrm{ml}$ liquid brown algae/1 liter of drinking fresh water had the greatest body weight gain, better feed conversion ratio, significant increases in total protein, albumin, and globulin and significantly decreases in total lipids and total cholesterol than that in the control chicks. On the other hands, water consumption and relative weight of carcass were not significantly affected by the algae supplementation. Histological observations concluded that birds, which received brown algae in drinking fresh water, had better intestinal health in terms of welldeveloped villi with their columnar epithelial lining, which indicative of an increase of the digestive and absorptive surface area leading to better nutrient utilization. These results suggested that liquid brown algae have a beneficial effects on the growth performance, intestinal development without any side effects and we can replace it with powder brown algae in broiler chicks, but we need more researches to confirm this item.

Keywords: liquid algae, broiler performance, blood parameters and intestinal histology.

\section{INTRODUCTION}

Marine algae can divide into three main groups, green, brown and red algae. It's a valuable source of food, trace elements and raw materials for the pharmaceutical industry and considered as the food supplement for $21^{\text {st }}$ century as source of proteins, lipids, polysaccharides, minerals, vitamins, enzymes and the pigmentation have in their cells is the one that make big differences between them (Rimber 2007 and Wei et al., 2013). Algae is a good source for essential nutrients, containing high amounts of proteins, amino acids, carbohydrate, lipids, vitamins $\left(\mathrm{A}, \mathrm{B}_{2}, \mathrm{~B}_{3}, \mathrm{~B}_{12}, \mathrm{C}, \mathrm{E}\right)$, nicotinic acid, biotin, folic acid, and pantothenic acid (David, 2001 and Becker, 2004). Algae are rich in pigments such as chlorophyll (0.5\% to $1 \%$ ) of dry weight and carotenoids (0.1 to 0.2\%) (Serviere-Zaragoza et al., 2002; Rimber, 2007; Abd El-Baky et al., 2008; and Al-Harthi and El-Deek, 2011, 2012). Brown algae (Ecklonia acva Kjellman, $E C$ ) contains $10.49 \%$ protein, $0.73 \%$ fat, $36.41 \%$ fiber, $27.23 \%$ mineral salts and $10.6 \%$ sodium chloride, and the average value of the energy represented by $1849 \mathrm{Kcal} / \mathrm{kg}$, and the average values of 13 amino acid is about $32 \%$ (Sim et al., 2004). In addition to the above, algae high in gamma linoleic acid, vitamin $\mathrm{B}_{12}$ and iron (Cohen and Vonshak, 1991; and Belay, 2002). Algae as a possible source of food for animal and human consumption have received increasing attention during the last three decades (Lorenze and Cysewski, 2000). Poultry birds like any living organisms also require feed ingredients, such as water, fats, inorganic elements, vitamins and feed additives like antibiotics and antifungal compounds (Tamiya, 1970). As regards poultry feed, seaweed can play an important role as stock feed and may serve as the 


\section{Abou El-naga and Megahed}

cheapest source as supplement of feeding. Algae has potential to be used in various animal feed including poultry and cattle; however, several variables are associated with production, thus necessitating research that compares methods of production and feeding value (Evans et al., 2015). Many studies have investigated dietary fiber in seaweed as a prebiotic in animal agriculture. Research involving pigs, lambs, cattle and chickens has been conducted using seaweed extracts and polysaccharides of brown and red seaweeds (Becker, 2004 and Seyed, 2015). It is a multipurpose product which is used in various industries, including fertilizer production, skin care products, cosmetics, soap making, also as an important active ingredient in some medicine and animal feeds and other food processed products (Msuya, 2013). El-Deek et al. (1987) found that inclusion of seaweeds in finisher broiler diets had no significant effects on growth, feed intake (FI) and feed conversion ratio (FCR). Other studies have also shown that, inclusion of $2.0 \%$ marine algae meal improved broiler performance and dressing percentage (Gu et al., 1988). Also, (Ventura et al., 1994; and Abudabos et al., 2013) found that the substitution of seaweeds in broiler diets had no adverse effects on broiler performance and addition of $4 \%$ seaweed in the chicken's basal diet led to increased body weight gain. Kulshreshtha et al. (2014) observed that laying hens fed with $2 \%$ red seaweed Chondrus crispus (CC) and 2\% Sarcodiotheca gaudichaudii (SG) affect feed conversion ratio for egg production. Low level $(0.5 \%)$ of supplemental (CC) and (SG) enhanced egg yolk weight and egg weight. Seaweeds as an animal feed addition include a large number of studies conducted on brown seaweed, Ascophyllum nodosum species. Tasco®, a natural, marine-plant based has positive effect on gut microbiota, growth performance and health of animals (Evans and Critchley 2013). Arata et al. (2011) found a positive effect on the growth of broilers in comparison with feed containing no additives. Wiseman (2012) observed that feeding birds with $0.5 \%$ Tasco improved BW and BWG. Gardiner et al. (2008) found that feeding pigs with $6 \%$ or $9 \%$ of Ascophyllum nodosum extract decreased ileal coliforms and increased Bifidobacterium in the cecal contents. Microalgae (Arthrospira) is used as a feed for a variety of animals, for example, aquarium fish, breeding bulls, cows, cats, dogs, horses, and ornamental birds. Algae have a positive impact on animal's physiology (Certik and Shimizu, 1999). In poultry feed, 5-10\% of microalgae can be used as a protein source. However, feeding microalgae for a long time and at higher concentrations will have adverse effects on poultry. The adverse effects of microalgae are mostly on the color of broiler skin and shanks and egg yolk. Some microalga species are specifically used as animal feed supplements. Worldwide, $30 \%$ of the current algal production is used for the production of animal feed (Becker, 2004) and more than 50\% of Arthrospira is grown for the production of feed supplement (Yamaguchi, 1996). In view of this, poultry farmers should be educated on the importance of using seaweed as feed ingredient or feed additive in their feed formulation. Poultry industry is very important and it generates income, provides employment and contributes in poverty reduction. However, the industry is faced with many challenges as far as poultry production is concerned, the crucial one being feed component. Feed is a major cost in the industry and normally accounts for about 70-80\% of the entire production expenditure (Ademola and Farinu, 2006). Additionally, Maurice et al. (1984) observed no adverse effect on growth, feed conversion ratio (FCR) or dressing percentage when sun dried Brazilian Elodea (Egeria densa) was added in broiler diets at 5.0\%. Poultry performance is influenced by nutrient supply in the diet amongst other factors and the demand of nutrients in poultry production varies based on their classes and physiological perspective. The nutrient demand of layer birds is quite different from that of broilers (Katule, 1994; BOA,1994; Todd and Roselina, 2014). In the intensive system of poultry production where birds are mostly kept indoors, they need to receive balanced diets so as to meet their daily physiological and production demands (McDonald et al., 2002). This means that each day birds need specific amount of protein, carbohydrate, fat, vitamins and minerals (James, 2008). The intake of a nutrient is an outcome of the amount of feed eaten and the level of nutrients in the feedstuffs or diets.

Therefor, the present study aimed to introduce the utilization of liquid brown algae (seaweed) as water supplementation on the productive performance and intestinal morphology of broiler chicks.

\section{MATERIALS AND METHODS}

A total number of 120 Indian River (IR) broiler chicks one-day old were divided randomly into 2 experimental groups of 3 replicates each has 20 chicks / battery cage $(100 * 60 * 40 \mathrm{~cm})$. Chicks were individually weighed to the nearest gram at one-day old, wing banded and randomly allotted to the 
dietary treatments and had free access to feed and water from nipple drinkers throughout the experimental period.

Basal diets were formulated according to the National Research Council's (NRC, 1994) nutrient values for ingredients, it contains $3000 \mathrm{kcal} \mathrm{ME} / \mathrm{kg}$ and $23 \%$ crude protein during the starter period till 21 day followed by $3000 \mathrm{kcal} \mathrm{ME} / \mathrm{kg}$ and $20.5 \%$ crude protein during the growing period till 35 day (Table 1). The experimental diets were designated as two treatments; $T_{1}$ and $T_{2 ;}$ treatment 1 represented as control (without liquid brown algae supplementation) and treatments 2 which have $1 \mathrm{ml}$ liquid brown algae; Seaweed; supplementation / 1 litter drinking fresh water.

Table (1): Composition and chemical analysis of the experimental diets fed during experimental periods (1-35) days of age.

\begin{tabular}{|c|c|c|}
\hline Ingredients & Starter period & growing period \\
\hline Ground yellow corn (8.5\%) & 48.60 & 57.58 \\
\hline Soybean meal (44 \%) & 42.92 & 35.56 \\
\hline Vegetable oil & 4.88 & 3.16 \\
\hline Dicalcium phosphate & 1.10 & 0.82 \\
\hline Limestone, ground & 1.70 & 2.10 \\
\hline Vitamin and mineral mixture ${ }^{1}$ & 0.30 & 0.30 \\
\hline Sodium chloride & 0.30 & 0.30 \\
\hline DL- methionine ${ }^{2}$ & 0.20 & 0.20 \\
\hline Total & 100 & 100 \\
\hline \multicolumn{3}{|l|}{ Calculated nutrient content ${ }^{3}$ : } \\
\hline Dry matter\% & 82 & 82 \\
\hline Crude protein, $\%$ & 23.01 & 20.53 \\
\hline $\mathrm{ME}, \mathrm{k}$ cal $/ \mathrm{kg}$ diet & 3015 & 3002 \\
\hline $\mathrm{C} / \mathrm{P}$ ratio & 131 & 146 \\
\hline Lysine, \% & 1.34 & 1.16 \\
\hline Methionine, \% & 0.56 & 0.53 \\
\hline Calcium, \% & 0.99 & 1.06 \\
\hline Available phosphorous, $\%$ & 0.50 & 0.53 \\
\hline \multicolumn{3}{|c|}{ 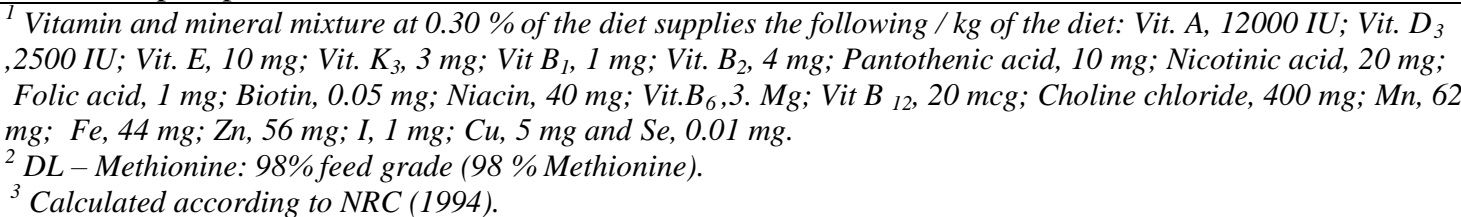 } \\
\hline
\end{tabular}

Light was provided continuously during night without interruption. Chicks in each replicate were weekly weighted and recorded their feed, water consumption and mortality. Body weight gain, feed conversion ( $\mathrm{g}$ feed/ g gain) and economic efficiency were calculated. Performance Index (PI) was calculated according to North (1984), equation as follow: PI = live body weight $(\mathrm{kg}) \times 100 /$ feed conversion. At 5 weeks of age, 6 chicks from each treatment representing their average body weight were randomly chosen and fasted (12 hours) and slaughtered to determine carcass traits; eviscerated carcass (without head, neck, and legs), total giblets (liver, gizzard and heart) and total edible parts (carcass + total giblets). Blood sample was collected from each group and separated by centrifugation at $3000 \mathrm{rpm}$ for 15 minutes. Total lipids, total cholesterol and triglycerides were determined using commercial kits and plasma total proteins and albumin were calorimetrically estimated. While, plasma globulin concentration was obtained by subtracting the concentration of albumin from total protein.

\section{Histological traits:}

During slaughter, the small intestines of chicks were removed immediately, after slaughtering, and segments of approximately $2 \mathrm{~cm}$ were taken from duodenum, jejunum and ileum for histological analysis. Segments referred to the midpoint of the duodenum (from gizzard to pancreo-biliary duct, duodenum), jejunum (the midpoint between the entry of the common bile duct and the Meckel's diverticulum), and ileum (from Meckel's diverticulum to ileocecal junction). Particular segments were 


\section{Abou El-naga and Megahed}

gently flushed and rinsed with $0.9 \%$ physiological saline and then fixed in a $4 \%$ neutral-buffered formalin solution for histological study. Intestinal samples were transferred from formaldehyde after dehydration by passing tissue through a series of alcohol solutions, were cleared by xylene and were embedded in paraffin. All samples were sectioned at $5-\mu \mathrm{m}$ thickness using a rotary microtome. Sections were sequentially transferred to glass slides and stained with Hematoxylin and Eosin (H \& E). After being dried, sections were analyzed under a light microscope. Morphometric measurements were performed on 9 villi chosen from each sample. The height of intestinal villi was measured from the tip to the base of villi at the opening crypt, and the villus width was measured at its midpoint (Geyra et al., 2001). The intestinal crypt depth was measured from the base of the villi to sub mucosa, and the muscular thickness from the sub mucosa to the external layer of the intestine (Geyra et al., 2001). The economic efficiency was calculated according to Heady and Jensen (1954) as follows: [(price of $\mathrm{kg}$ weight gain - feed cost $/ \mathrm{kg}$ gain)/feed cost $/ \mathrm{kg}$ gain $\times 100$ ] under local conditions.

\section{Statistical Analysis:}

Data were statistically analyzed by the completely randomized design using SPSS (2011) program and the differences among means were determined using Duncan's multiple range test (Duncan, 1955). Percentages were transformed to the corresponding arcsine values before performing statistical analysis. $Y_{i j}=\mu+\alpha_{i}+e_{i j}$ Where: $Y_{i j}=$ an observation. $\mu=$ Overall mean. $\alpha_{i}=$ effect of treatment $(\mathrm{I}=1,2,3,4, \ldots . .7)$, and $e_{i j}=$ Random error.

\section{RESULTS AND DISCUSSION}

Growth performance parameters of Indian River (IR) chicks as affected by liquid seaweeds brown algae (BA, Ascophyllum nodosum) $1 \mathrm{ml} /$ litter fresh water along with commercial feeds are presented in Tables (2 and 3). Results showed that from the first to fifth week of feeding period, the weight of the chicks of the control group was not as good as the tested chicks. While, chicks have $1 \mathrm{ml} \mathrm{BA} /$ litter fresh water was significantly heavier body weight than the un-supplemented chicks by about $15.21 \%$ and $13 \%$ at the third and fifth week of age, respectively. Also, body weight gain/d and performance index were significantly increased by the addition and have corresponding values of $10.23,13.25 \%$ and 30.29 , $49.11 \%$, respectively during the starter and marketing age compared to the control group. This improvement may be due to that algae may contain non-protein nitrogen (such as free nitrate), resulting in an overestimation of their protein content (Makkar et al., 2015). Chicks have $1 \mathrm{ml} \mathrm{BA/} \mathrm{litter} \mathrm{fresh}$ water significantly recorded the lowest amount of feed consumption at the third and fifth week of age (58.64 and $103.50 \mathrm{~g} /$ chick/day), respectively compared to 60.05 and $115.75 \mathrm{~g} /$ chick/day at the un supplemented chicks. Feed conversion ratio was significantly improved $(\mathrm{P} \leq 0,05)$ by liquid brown algae supplementation and recorded 1.78 compared to 2.26 in the control group at marketing age (5 weeks), this is may be due to the improvement in live body weight or in the improvement of viability percentage. Costa et al. (2013) showed that there was no significant effect of increasing levels of A. nodosum meal up to $20 \mathrm{mg} \mathrm{kg-1}$ on body weight, but feed conversion ratio and carcass yield were improved. Water consumption was not significantly affected by the supplementation, chicks consumed approximately equal amount of water. Increasing body weight and body weight gain led to improving the efficiency of feed utilization. Mariey et al. (2012) reported that feeding algae diets may increase the lactobacillus population and enhance the absorption of dietary vitamins. Choi et al. (2014) noted that chicks have $4 \%$ of seaweed gain the best live body weight, body weight gain and feed conversion ratio. Armin et al. (2015) found that feed intake was lower in chicks fed diets supplemented with different levels of marine algae (5 and 10\%) and led to an improvement in feed conversion ratio. Ali and Memon (2005) noted that from the first to the tenth week feeding period, chick's weight in the control group was not very good as compared to the tested chicks. On the other hand, Gardiner et al. (2008) reported that seaweeds contain chelating minerals that caused anion-cation imbalance and depression in growth. Therefore, high content of alginate in marine algae can decrease daily feed consumption. This reduction in feed consumption can be related to the high content of fiber in the algae biomass (Carrillo et al. 2008).

Moreover, algae contain high concentrations of phenolic compounds, which reduce feed intake, nitrogen retention and nitrogen digestion (De Lange, 2000). Effect of brown algae in mortality ratio is presented in Table (4). 
Table (2): Effect of liquid brown algae supplementation in the performance of Indian River (IR) chick.

\begin{tabular}{lcccc}
\hline \multirow{2}{*}{ Parameters } & \multicolumn{2}{c}{ Treatments } & \multirow{2}{*}{ SEM } & \multirow{2}{*}{ P-value } \\
\cline { 2 - 5 } & Control, $\mathrm{T}_{1}$ & $\mathrm{~T}_{2}, 1 \mathrm{ml}$ brown algae/ Litter & & \\
\hline Initial body weight, g & 43 & 43 & 000 & $\mathrm{NS}$ \\
body weight at 3 weeks, g & $858.20^{\mathrm{b}}$ & $988.75^{\mathrm{a}}$ & 4.63 & $*$ \\
body weight at 5 weeks, kg & $1.84^{\mathrm{b}}$ & $2.08^{\mathrm{a}}$ & 14.73 & $*$ \\
body weight gain/d at 3 weeks, g & $40.86^{\mathrm{b}}$ & $45.04^{\mathrm{a}}$ & 0.30 & $*$ \\
body weight gain/d at 5 weeks, g & 51.34 & 58.14 & 1.88 & $\mathrm{NS}$ \\
Performance index at 3 weeks & 58.38 & 76.06 & 1.68 & $*$ \\
Performance index at 5 weeks & 78.30 & 116.74 & 2.66 & $*$ \\
\hline
\end{tabular}

Table (3): Effect of liquid brown algae supplementation in the performance of Indian River (IR) chick.

\begin{tabular}{|c|c|c|c|c|}
\hline \multirow{2}{*}{ Parameters } & \multicolumn{2}{|r|}{ Treatments } & \multirow{2}{*}{ SEM } & \multirow{2}{*}{ P-value } \\
\hline & Control, $\mathrm{T}_{1}$ & $\mathrm{~T}_{2}, 1 \mathrm{ml}$ brown algae/ Litter & & \\
\hline Feed consumption at 3 weeks, $g$ & 60.05 & 58.64 & 0.18 & $*$ \\
\hline Feed consumption at 5 weeks, $g$ & 115.75 & 103.50 & 1.06 & $*$ \\
\hline Feed conversion at 3 weeks & 1.47 & 1.30 & 0.01 & * \\
\hline Feed conversion at 5 weeks & 2.26 & 1.78 & 0.02 & * \\
\hline Water consumption at 3 weeks, $\mathrm{ml}$ & 110.00 & 105.00 & 0.18 & NS \\
\hline Water consumption at 5 weeks, $\mathrm{ml}$ & 210.00 & 200.00 & 0.35 & NS \\
\hline
\end{tabular}

Table (4): Effect of liquid brown algae supplementation in the mortality ratio of Indian River (IR) chick.

\begin{tabular}{|c|c|c|c|c|c|}
\hline \multirow[t]{2}{*}{ Weeks } & \multirow{2}{*}{$\begin{array}{c}\text { Temperature, } \\
\mathrm{C}^{\circ} \\
\end{array}$} & \multicolumn{2}{|r|}{ Mortality chicks } & \multirow{2}{*}{ SEM } & \multirow[b]{2}{*}{ P-value } \\
\hline & & Control, $\mathrm{T}_{1}$ & $\mathrm{~T}_{2}, 1 \mathrm{ml}$ brown algae/ Litter & & \\
\hline First weeks & 33 & 1 & - & 0.11 & * \\
\hline Second weeks & 35 & 1 & - & 0.11 & * \\
\hline Third weeks & 35 & 1 & - & 0.10 & * \\
\hline Fourth weeks & 38 & 1 & - & 0.09 & $*$ \\
\hline Fifth weeks & 40 & 3 & 2 & 0.10 & NS \\
\hline Total & & 7 & 2 & --- & NS \\
\hline Mortality. \% & & 11.67 & 3.33 & --- & $*$ \\
\hline
\end{tabular}

Mortality rate was significantly affected by the supplementation and recorded zero $\%$ in chicks supplemented with $1 \mathrm{ml} \mathrm{BA/} 1$ Litter fresh water from the first to the fourth week of age compared to the un supplemented chicks (6.7\%). This indicated that BA (Ascophylum nodosum) is non- toxic. Mortality and the clinical health of all chicks were monitored daily and mortality rate percentage was calculated as a number of dead chicks at the end of a certain period relative to the initial number of live chicks. In the fifth weeks of age, mortality rate was slightly increased but less than the control chicks and recorded $3.33 \%$ in supplemented chicks vs. $5.36 \%$ in the un-supplemented chicks. This mortality ratio may be related to the high environmental temperature $\left(40 \mathrm{C}^{\circ}\right)$ during this week of age and not related to the supplementation. The present findings are also supported by Ali and Memon (2005). Previous studies indicated that supplementing Tasco ${ }^{\circledR}$ in the diet of animals under stress conditions such as livestock transportation, and increased environment temperature cause a reduction in the effect of the stress among animals to be resistant in stress conditions (Fike et al., 2001). Brown and Miller (1992) noted that the vitamin content of algal biomass can vary significantly among species; especially ascorbic acid which plays a major role in heat stress resistance. 


\section{Abou El-naga and Megahed}

\section{Carcass characteristics:}

The results recorded about carcass characteristics of IR chicks are presented in Table (5). Chicks had BA in fresh water have heavier carcass weight (1666.67 vs. $1480 \mathrm{~g})$, but the relative weight of carcass traits studied was not significantly affected by dietary treatments (ranged between 81.30 vs. 79.99) at 5 weeks. These results are in agreement with El-Deek et al. (2011) who showed that using different levels of algae in broiler finisher diets had in significant effect on dressing percentages, gizzard and spleen percentages at 39 days of age. Also, Kovac et al. (2013) noted that small amounts of algae used in feeding at different animals, have been created to improve the immune system, increasing weight, number of eggs, improving reproductive performance or reducing cholesterol levels, indicating the possibility of new farming methods in order to improve the quality of meat and eggs.

Table (5): Effect of liquid brown algae supplementation in carcass of Indian River (IR) chick.

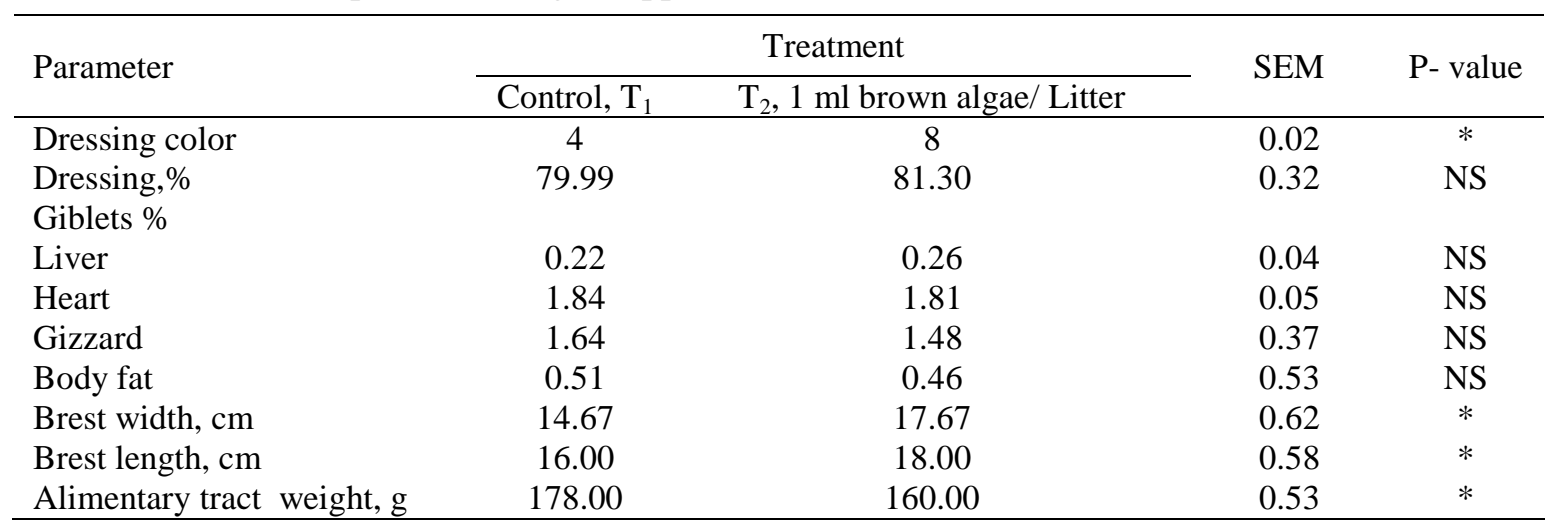

Schaivone et al. (2007) reported that using $5 \mathrm{~g}$ algae/ $\mathrm{kg}$ diet in significantly affected slaughter characteristics, chemical structure, color, stability of oxidation properties and sensory of the Muscovy ducts. On the other hand, Eman (2017) found that brown algae supplementation (3.5\%) significantly increased dressing percentage $(75.20 \%)$, giblets percentage and lower abdominal fat $(1.22 \%)$ compared to other dietary treatments.

Data also revealed that brown algae supplementation significantly increased dressing color, breast width and length compared to the un-supplemented chicks, but significantly decreased alimentary tract weight. For pigmentation of broilers and egg yolk, formulated feeds traditionally contain dehydrated alfalfa meal and/or corn, both of which are rich sources of lutein and zeaxanthin. Seaweed biomass has been reported to increase the pigmentation of egg yolk when used at a dietary inclusion level of $15 \%$ (Strand et al. 1998). Gouveia et al. (1996) reported that Chlorella vulgaris biomass produced yolk pigmentation comparable to other commercially used pigments. Chlorella is not only credited with improving the health status of laying hens but also with improving egg quality and pigmentation (Halle et al. 2009). According to Waldenstedt et al. (2003), H. pluvialis also has good potential as a natural pigment enhancer in broiler chickens. The yellow dressing color may be due to the dominance of the xanthophyll's pigment fucoxanthin, which masks the chlorophylls, beta - carotene and other xanthophylls (Guiry, 2014).

\section{Blood parameters:}

Data presented in Table (6) showed the concentrations of total protein, albumin (A), globulin $(G)$ and $\mathrm{A} / \mathrm{G}$ ratio in blood serum were significantly increased by the supplementation of $1 \mathrm{ml} \mathrm{BA} / 1$ litter fresh water. This improvement may be due to the good absorption of brown algae and its protein content (5- 12\%, Makkar et al. 2015). Kritchevsky et al. (1999) and Hassan et al. (2005) noted that brown meal algae (BMA) showed a beneficial effect on plasma high-density lipoprotein cholesterol (HDL), lowdensity lipoprotein (LDL), total cholesterol and triglycerides which could be attributed to algae sterols. Rimber (2007) and El- Deek et al. (2011) found that algae were a valuable human and animal nutrition because of its protein, amino acid, fiber minerals, fatty acids and bioactive content. Jimenez-Escrig and Cambrodon (1999) revealed that revealed that this might be due to its sterol and poly sachcarides content (alginic acid, fucoidan, cellulose, xylose and glucouronic acid). Total lipids and total cholesterol were significantly decreased by the supplementation of liquid brown algae. Chicks have $1 \mathrm{ml} \mathrm{BA} 1$ litter fresh 
water have 390 and $123.33 \mathrm{mg} / \mathrm{dl}$, respectively in total lipids and total cholesterol compared to 450 and $145 \mathrm{mg} / \mathrm{dl}$ at the control group.

Table (6): Effect of liquid brown algae supplementation in some blood parameters of Indian River (IR) chick.

\begin{tabular}{lcccc}
\hline \multirow{2}{*}{ Parameters } & \multicolumn{2}{c}{ Treatments } & \multirow{2}{*}{ SEM } & P-value \\
\cline { 2 - 4 } & Control, $\mathrm{T}_{1}$ & $\mathrm{~T}_{2}, 1 \mathrm{ml}$ brown algae/ Litter & 0.14 & $*$ \\
Total protein, g/ dl & 4.35 & 5.20 & 0.12 & $*$ \\
Albumin (A), g/ dl & 3.04 & 3.73 & 0.03 & $*$ \\
Globulin (G), g/ dl & 1.31 & 1.47 & 0.04 & $*$ \\
A/ G ratio & 2.32 & 2.54 & 12.02 & $*$ \\
Total lipids, mg/ dl & 450.00 & 380.00 & 4.41 & $*$ \\
Total cholesterol, mg/ dl & 145.00 & 123.33 & & \\
\hline
\end{tabular}

In accordance with the present results, Al-Harthi and El- Deek (2012) and Armin et al. (2015) reported that brown algae supplementation (3\% and 6\%) significantly reduced plasma total cholesterol compared to the control group. On the other hand, (Al-Harthi and El-Deek, 2012) found that the different processing methods had no significant effect on plasma total lipid, triglycerides, total cholesterol, HDL and LDL, calcium or alkaline phosphatase levels.

\section{Histological observations:}

The histological examination of the intestinal sections from birds duodenum showed considerable changes associated with treatments applied (Figs. 1 and 2). It's clear that the number of villi per microscopic field was more abundant in the $\mathrm{T}_{2}$ treatment $(1 \mathrm{ml}$ liquid brown algae; Seaweed; supplementation / 1 litter fresh water, Fig. 2) compared to the $T_{1}$ section (un supplemented with liquid brown algae, Fig. 1). Moreover, the villi width and heights were greater in the $T_{2}$ than $T_{1}$ sections with heights organized epithelial lining of the villi sections. Also, the number and size of the crypts of the lieberkühn (cr) were greater in $T_{2}$ sections than $T_{1}$, although some large crypts could be seen in $T_{1}$ sections. The muscular mucosas along with the sub - mucosa layer diameter were also greater in $\mathrm{T}_{2}$ than $\mathrm{T}_{1}$ sections. A similar trend was also observed in the jejunum sections, where the villi highet and diameter were greater in $\mathrm{T}_{2}$ section than $\mathrm{T}_{1}$ (Fig. 3 and 4 ). The number and size of crypts were also greater in $T_{2}$ than $T_{1}$ sections. The effect was also extended to ileum sections where $T_{2}$ treatment showed an important in all items compared to $\mathrm{T}_{1}$ sections (Fig. 5 and 6). Although the number of crypts was greater in the $T_{1}$ section (Fig. 5) there size and epithelial lining were not developed when compared to $T_{2}$ crypts.

\section{Histological sections:}

From the previous observations, it's concluded that birds from $\mathrm{T}_{2}$ treatment $(1 \mathrm{ml}$ liquid brown algae; Seaweed; supplementation/ 1 litter fresh water) had better intestinal health in terms of welldeveloped villi with their columnar epithelial lining indicative of an increase of the digestive and absorptive surface area leading to better nutrient utilization. This improvement in the villi appearance was greater in ileum sections. Following by jejunum and then duodenum segments are the main absorptive parts in the digestive tract. Of great interest, the variation in the number and size of the crypts, which were greater in $T_{2}$ than $T_{1}$ sections. These crypts are known to have the ability to secret fluids containing different vital substances essential for enhancing the internal micro- environmental of the intestinal segments (Hodges, 1974). These fluids are rapidly observed from the villi lumens, making a closed circulation from crypts to villi which results in a watery vehicle supply for improving absorption of nutrients, elaboration and production of antibodies and lymphocytes, along with an increase in global cells which secret substances responsible for reducing $\mathrm{pH}$ in the intestine and enhancing immunity. These results are in accordance with these reported by Pelicano et al. (2005) and Samli et al. (2007).

\section{Economic efficiency:}

Results concerning economic efficiency evaluation of 1ml BA/ 1 litter fresh water in Indian River chicks are presented in Table (7). The highest relative economic efficiency value was observed with chicks have $1 \mathrm{ml}$ brown algae/1 litter fresh water (136.90\%) compared to (100\%) in the un supplemented chicks. Also, European efficiency index confirm these results and the tested chicks had 315.77 compared to 222.43 in the control group. 


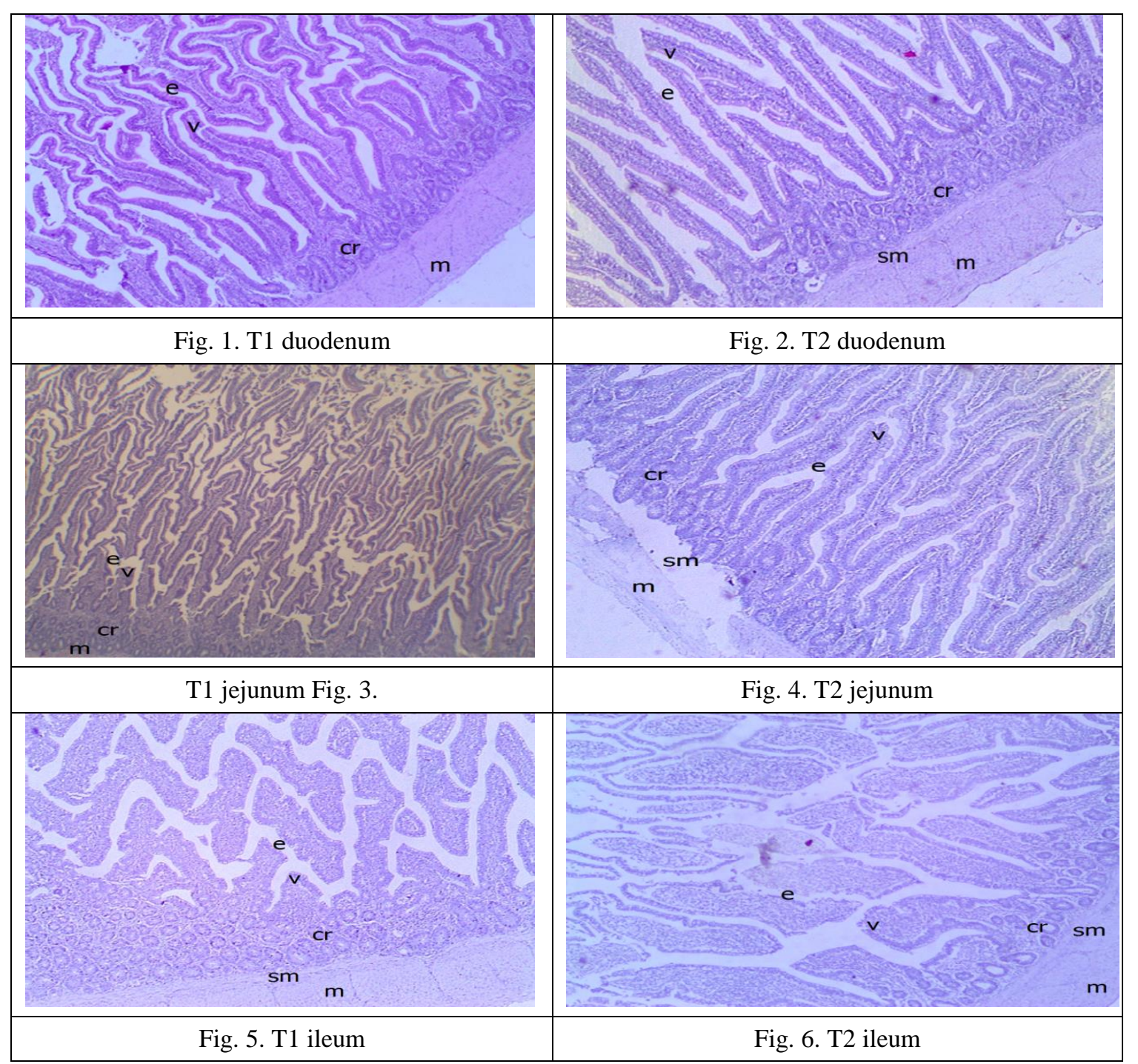

Figs. (1-6): The histological examination of the intestinal sections from bird's treatments applied whereas: e: epithelial lining, v: villi, cr: crypts of lieberkuhn, sm: sub mucosa layer, m: muscular mucosa. 
Table (7). Effect of liquid brown algae supplementation on the economic efficiency of Indian River (IR) chick.

\begin{tabular}{lcc}
\hline \multirow{2}{*}{ Parameter } & \multicolumn{2}{c}{ Treatment } \\
\cline { 2 - 3 } & Control, $\mathrm{T}_{1}$ & $\mathrm{~T}_{2}, 1$ ml brown algae/ Litter \\
\hline Initial body weight, $\mathrm{g}$ & 43 & 43 \\
Final body weight, $\mathrm{kg}$ & 1.84 & 2.08 \\
Body weight gain, $\mathrm{kg}$ & 1.79 & 2.04 \\
Total revenue, $\mathrm{LE}^{2}$ & 44.75 & 50.93 \\
Feed intake, kg & 4.05 & 3.62 \\
Price of kg feed, $\mathrm{LE}^{3}$ & 6.50 & 6.50 \\
Price of liquid algae, $\mathrm{LE}^{4}$ & - & 0.09 \\
Feed cost, LE & 24.30 & 23.68 \\
Net revenue, $\mathrm{LE}^{5}$ & 20.45 & 27.25 \\
Economical Effeciency & 6 & 1.15 \\
Relative economical efficiency & 0.84 & 136.90 \\
European Efficiency index $^{7}$ & 100 & 315.66 \\
\hline
\end{tabular}

${ }^{\mathrm{I}} T_{1}$; control, $T_{2}$; control $+10 \mathrm{ml}$ liquid brown algael litter.

${ }^{2}$ Price of one kg live body weight was 25 L.E.

${ }^{3}$ Price of one litter liquid algae 300 L.E.

${ }^{4}$ Net revenue $=$ Total revenue - Feed cost .

${ }^{5}$ Economical efficiency $=$ Net revenue $/$ Feed cost .

${ }^{6}$ European efficiency index, EEI $=($ Mean body weight $(\mathrm{kg}) \times$ livability $\%) /($ marketing age, days $\times$ feed conversion ratio) $\times 100$, cited by Soltan and Kusainova, (2012).

\section{REFERENCES}

Abd El-Baky, H.H., F.K. El Baz, G.S. El-Baroty, (2008). Evaluation of Marine Alga Ulva lactuca L. as a source of natural preservative ingredient. Am-Eurasian J. Agric. Environ. Sci. 3:434-444.

Abudabos, A. M., A. B. Okab, R. S. Aljumaah, E. M. Samara, K. A. Abdoun and A. A. Al-Haidary, (2013). Nutritional value of green seaweed (Ulva lactuca) for broiler chickens. Italian Journal of Animal Science 12 (2): 28-34.

Ademola, S. G. and G. O. Farinu, (2006). Performance of the laying birds fed diets containing forage meal of Tithonia diversifolia (Hamsi A.G.) and Antibiotics. Nigeria Journal Animal Production, 33: 58-68.

Al-Harthi, M. A., A. A. El- Deek, (2012). Effect of different dietary concentrations of brown marine algae (Sargassum dentifebium) prepared by different methods on plasma and yolk lipid profiles, yolk total carotene and lutein plus zeaxanthin of laying hens. Ital. J. Anim. Sci. 11, 64.

Al-Harthi, M.A., A.A. El-Deek, (2011). The effects of preparing methods and enzyme supplementation on the utilization of brown marine algae (Sargassum dentifebium) meal in the diet of laying hens. Ital. J. Anim. Sci. 10:e48.

Al-Harthi, M.A., A.A. El-Deek, (2012). Nutrient profiles of brown marine algae (Sargassum dentifebium) as affected by different processing methods for chicken. J. Food Agric. Environ. $10: 475-480$

Ali, A., M. S. Memon, G. A. Sahato and S. N. AArbani (2005). Use of fresh water algae Spirogyraa ellipssossporaa traannseau as feed supplement to broiler chicks. Haamdaardd Medicus. Vol XL. VIII. NO. 3. 2005.

Arata, M., Anderson D., Rathgeber B. and F. Evans, (2011). Evaluation of Tasco® -supplemented broiler diets as a candidate prebiotic. Poult. Sci. (E-Suppl. 1). p.14 


\section{Abou El-naga and Megahed}

Armin, F., S. Rahimi, A. A., Mahdi, I. Y. Ghofrani and H. Ebrahim, (2015). Effect of Srgassum sp. And vitamin $\mathrm{E}$ on stability of fish oil enriched meat in broiler chickens. Iranian J. App. Anim. Sci., 5(2): 385- 392 .

BOA, (1994). Board of Agriculture. Nutrient Requirement of Poultry, ninth Edition National Academy of Science. 19pp.

Becker, E. W. (2004). Microalgae in human and animal nutrition. P. 312- 351. In (Ed. A. Richmond). Handbook of microalgae culture. Blackwell, Oxford.

Brown, M.R. and K.A., Miller (1992). The Ascorbic Acid Content of Eleven Species of Microalgae Used in Mariculture. In: J. Appl. Phycology 4/3 (1992), pp. 205-215

Belay, A. (2002). The potential application of Spirulina (Arthrospira) as a nutritional and therapeutic supplement in health management. J. Am. Nutraceutical Assoc. 5: 27- 48.

Carrillo, S., E. Lopez, M. M. Casas, E. Avila, R. M. Castillo, M. E. Carranco, C. Calvo and F. Perez- Gil (2008). Potential use of seaweeds in the laying hens ration to improve the quality of $\omega 3$ fatty acid enriched eggs. J. Appl. Phycol., 20: 721- 728.

Certik, M., and S. Shimizu (1999). Biosynthesis and regulation of microbial polyunsaturated fatty acid production. J. Biosci. Bioeng., 87:1-14.

Choi, Y.J., S.R. Lee and J.W. Oh (2014). Effects of dietary fermented seaweed and seaweed fusiforme on growth performance, carcass parameters and immunoglobulin concentration in broiler chicks. Asian Austr. J. Anim. Sci., vol. (27), No. 6: 862- 872.

Cohen. Z., and A. Vonshak (1991). Fatty acid composition of Spirulina and Spirulina-

like cyanobacteria in relation to their chemotaxonomy. Phytochemistry 30: 205- 206.

Costa, M.M, S.T.L. Oliveira, R.E. Balen, G. J. Bueno, L.T. Baldan, L. C. R. Silva and L.D. Santos, (2013). Brown seaweed meal to Nile tilapia fingerlings. Arch Zootec 62:101-109.

David (2001). Overview of Sea Vegetable Chemical Composition. www. surialink.com.

De Lange, C. F. M. (2000). Overview of detrimental of the nutritional value of feed ingredients. P 17- 32 in Feed evaluation principles and practices. P. J. Visser- Reyneveld, Eds. Wageningen Press, Netherlands.

Duncan, D.B. (1955). Multiple range and Multiple Test. Biometrics, 11: 1-42.

El-Deek, A. A., M. A. Asar, M. A. Safaa, and M. A. Kosba, (1987). Nutritional value of marine seaweed in broiler diets. Journal of Agriculture Science 12: 707 - 717.

El-Deek.A. A., M. A., Al-Harthi, A. A. Abdalla, M. M. Elbanoby (2011). The use of brown algae meal in finisher broiler diets. Egypt Poul. Sci., 1.31. 767- 781.

Eman, A. H. (2017). Effect of dietary brown algae supplementation on the performance of broiler chicks. Meno. J. Anim. Poul. And Fish Prod., vol (2, 2018): 11-22.

Evans, F. D., and A. T. Critchley, (2013). Seaweeds for animal production use. J. Appl. Phycol. 26:891899.

Evans, A. M., D. L. Smith and J. S. Mortiz, (2015). Effects of algae incorporation into broiler starter diets formulations on nutrient digestibility and 3 to $21 \mathrm{~d}$ bird performance. J. Appl. Poul. Res. 24: 206- 214.

Fike J. H., V. G. Allen, R. E. Schmidt, X. Zhang, J. P. Fontenot, C. P. Bagley, R. L. R. R. Ivy Evans, R.W. Coelho and D. B. Wester, (2001). Tasco-forage: 1. Influence of a seaweed extract on antioxidant activity in tall fescue and in ruminants. J Anim Sci 79:1011-1021.

Gardiner, G. E., A. J. Campbell, J. V. O'Doherty, E. Piercr, P. B. Lynch, F. C. Leonard, C. Stanton, R. P. Ross and P. G. Lawlor (2008). Effect of Ascophyllum nodosum extract on growth performance, digestibility, carcass characteristics and selected intestinal microflora populations of grower finisher pigs. Anim. Feed Sci. Technol., 141: 259- 273. 
Geyra, A., Z. Uni, and D. Sklan (2001). Enterocyte dynamics and mucosal development in the post hatch chick. Poult. Sci.80:776 -782.

Gouveia, L., V., Veloso, A. Reis, H., Fernandes, J., Novais and J., Empis, (1996). Chlorella vulgaris Used to Colour Egg Yolk. In: Journal of the Science of Food and Agriculture 70/2 (1996), pp. 167172.

Gu, H. Y., Y. G., Liu, and Z. Z., Shu, (1988). Nutrient composition of marine algae and their feeding on broilers. Chinese J. Anim. Sci. 3: $12-14$.

Guiry, M. D. (2014). The seaweed site: information of marine algae, Seaweed.

Halle, I.; P., Janczyk, G. Freyer, and W. B., Souffrant, (2009). Effect of Microalgae Chlorella vulgaris on Laying Hen Performance. In: Archiva Zootechnica 12/2 (2009), pp. 5-13.

Hassan Nia, M.R., B.M. Gharanjik and A.A. Dadghani (2005). Effects of marine algae on egg cholesterol. Iran. J. Food Sci. Tech. 24:11- 19.

Heady, E. O. and H. R., Jensen, (1954). Farm Management Economics. Pentice - Hall Inc. Englewood Cliffs, N.J., USA. In china.

Hodges, R. D. (1974). The histology of the fowl. $2^{\text {nd }}$ Ed. Academic press. Lonndon.

Jacob, J. (2015). Seaweed in poultry diets. Small and backyard flocks. University of Kentucky.

James, H. (2008). Supplemented feed for Poultry. [http://www.smallfarms.oregonstate edu/sfn/f08poultry] site visited on 2/5/2015.

Jimenez-Escring, A. and C. I., Goni, (1999). Nutritional evaluation and physiological effects of edible seaweeds. Arch. Latinoam. Nutr. 49: 114-120.

Katule, A. M. (1994). Fundamental of Modern Poultry Management. Compendium Lecture Notes Produced at the Department of Animal Science and Production, Sokoine University of Agriculture, Morogoro, Tanzania. 53 - 96pp.

Kovac, J. D., B. S. Jelia, B. B., Olivera, C. M., Aleksandra and M. Li. Ivan, (2013). Algae in food and feed. J. inist. F. Technol. In Novi Sad. Vol (40), Issue 1: 21- 32.

Kritchevsky, D., S.A. Tepper, S.K. Czarnecki and D.J. Kyle, (1999). Effects of 4-methylsterols from algae and of $\beta$ sitosterol on cholesterol metabolism in rats. Nutr. Res. 19:1649-1654.

Kulshreshtha, G., B. Rathgeber, G. Stratton, N. Thomas, F. Evans, A.Critchley, J. Hafting and B. Prithiviraj, (2014). Immunology, Health, And Disease feed supplementation with red seaweeds, Chondrus crispus and Sarcodiotheca gaudichaudii, affects performance, egg quality, and gut microbiota of layer hens. Poult. Sci. 93:2991-3001.

Lorenze, R. T. and G. R. Cysewski (2000). Commercial potential for Naematococcus microalgae as a natural source of astaxanthin. Trends Biotech. 18 (4). Pp 160- 167.

Makkar H. P. S., G. Tran, V. Heuze, S. G. Reverdin, M. Lessire and F. Lebas, (2015). Seaweeds for livestoc diets: A review. Anim. F Sci. Tech. ANIFEE 13381. No of pages 17.

Mariey, Y. A., H. R. Samak, M. A. Ibrahem, (2012). Effect of using spirulina platensis algae as a feed additive for poultry diets: 1- Productive and reproductive performances of local laying hens. Egypt. Poult. Sci., Vol. (32). (1): pp. 201- 215.

Maurice, D. V., J. E. Jones, C. R. Dillon and J. M. Weber, (1984). Chemical composition and nutrition value of Brazilian elodea (Egeria densa) for the chick. Poultry Science 63: 317- 476.

McDonald, P., A. Edwards, J. F. D. Greenhalgh and C. A. Morgan, (2002). Animal Nutrition 6th Edition. Pearson Education Limited, Edinburgh Gate, Harlow Essex CM20 2JE England. 432pp.

Msuya, F. E., (2013). Social and economic dimensions of carrageenan seaweed farming in the United Republic of Tanzania. Social and economic dimensions of carrageenan seaweed farming. Fisheries and aquaculture Technical Paper, (580).

NRC, National Research Council (1994). Nutrient requirements of Poultry. 9th Rev. Edn. National Academy Press, Washington, DC. 


\section{Abou El-naga and Megahed}

North, M.O, (1984). Commercial chicken production manual. 3rd ., The AVI, Publishing co. Inc., West port, Connecticut, U.S.A.

Pelicano, E. R., P. A. Souza; H. B. Souza; D. F. Figueiredo; M. M. Boiago; S. R. Carvalho and V. F. Bardon, (2005). Intestinal mucosa development in broiler chickens fed natural growth promoters. Res. Brasil. Cienc. Avicc, 4: 221- 229.

Rimber Ir. Indy, (2007). Why is seaweed so important? M.Sc thesis Faculty of Fisheries and Marine Sciences, Sam Ratulangi University, Jln. Kampus Bahu, Manado 95115, Indonesia.

Samli. H. E., N. S. Senkoylu, F. Koc, M. Kanter and A. Agma, (2007). Effects of enterococcus faecium and dried whey on broiler performance, gut histomorphology and intestinal microboita.. Archives of Anim. Nutrition, 61: 42- 49.

Schaivone, A., R. Chiarini, M. Marzoni, A. Castillo, S. Tasoneand and I. Romboli, (2007). Breast meat traits of Muscovy ducks fed on a microalgae (Crypthecodinium cohnii) meal supplemented diet. Brit. Poule. Sci., 48: 573- 579.

Serviere-Zaragoza, E., D. Gómez-lopez and G. Ponce-Díaz, (2002). Gross chemical composition of three common macroalgae and a sea grass on the Pacific coast of Baja California, Mexico. Hidrobiologica 12:113-118.

Seyed, H. K., (2015). Effects of Red Seaweed (Palmaria palmata) Supplemented Diets Fed to Broiler Chickens Raised under Normal or Stressed Conditions. M. Sc. at Dalhousie University Halifax, Nova Scotia September 2015.

Sim. J. M., C. W. Kang, S. K. Kim, S.K. Kwon, B. K.; An, K. K. Park, and E. Her, (2004). Nutritional evaluation of brown marine algae and lection extract residue for poultry feeding. XXII World's Poultry Congress, WPSA, June 8-12, Istanbul, Turkey.

Soltan, M. E. and Z. Kusainova, (2012). Performance of broiler chickens in different farming with different feed conversion under Egyptian conditions.

SPSS., (2011). SPSS 11.0 for Windows. SPSS Inc., Chicago. Standardization administration of china. 2005.

Strand, A., O. Herstad and S. Liaaen-Jensen, (1998). Fucoxanthin Metabolites in Egg Yolks of Laying Hens. In: Comparative Biochemistry and Physiology 119/4 (1998), pp. 963-974

Tamiya, H., (1970). Role of algae as a food. Proe, Symp. Algalogy (New Delhi). Indian Council Agri. Res. PP: 379- 399.

Todd, J. A. and A. Roselina (2014). Nutrients Requirements of Poultry Publication. History and need for an update. University of Animal and Avian Science, University of Maryland. 574pp.

Ventura, M. R., J. I. R. Castanon, and J. M. McNab, (1994). Nutritional value of seaweed (Ulva rigida) for poultry. Animal Feed Science and Technology 49(1): 87- 92

Waldenstedt, L.; J. Inborr, I. Hansson, and K. Flwinger, (2003). Effects of Astaxanthin-rich Algal Meal (Haematococcus pluvialis) on Growth Performance, Caecal Campylobacter and Clostridial Counts and Tissue Astaxanthin Concentration of Broiler Chickens. In: Animal Feed Science and Technology 108/1-4 (2003), pp. 119-132

Wei, N., J. Quarterman and Y. S. Jin, (2013). Marine macroalgae: an untapped resource for producing fuels and chemicals. Trends in Biotechnology 31(2): 70-77.

Wiseman, M. (2012). Evaluation of Tasco® as a candidate prebiotic in broiler chickens. MSc. Thesis. Faculty of Agriculture, Dalhousie University. Pp. 113-114.

Yamaguchi, K (1996). Recent advances in micro algal bioscience in Japan, with special reference to utilization of biomass and metabolites: a review. J Appl. Phycol. 8:487-502.

Zahid, P. B., A. Abid and M. J. Zahid, (2001). Brown seaweeds as supplement for broiler feed. Hamdard Medicus vol XLIV, no. 2, 2001. 
تأثير إضافة الطحالب البنية السائلة في مياه الثرب على الأداء الإتتاجى والتغير الهستولوجي فى كتاكيت التسمين

منال كمال أبو النجاا و محمد محروس مجاهد

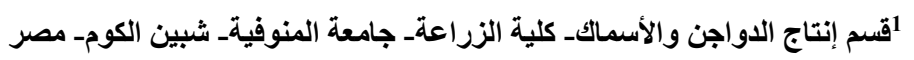

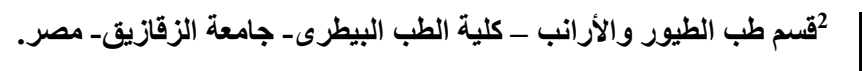



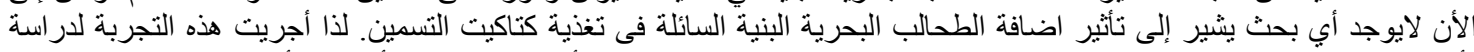

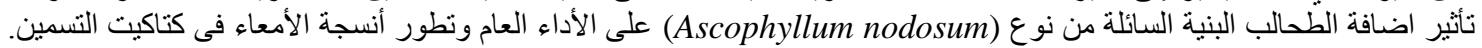

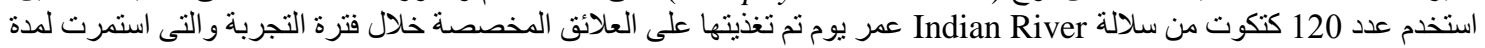
35 يوم. تم اضافة الطحالب البنية السائلة إلى مياه الثرب بمستوى صفر ر ر مل/ لتر ماء.

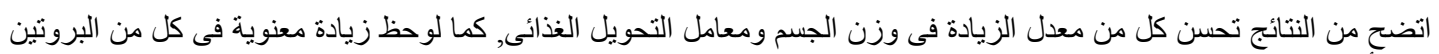

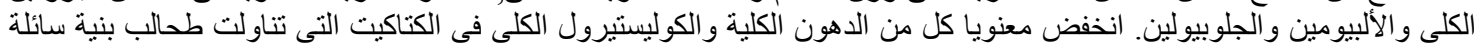

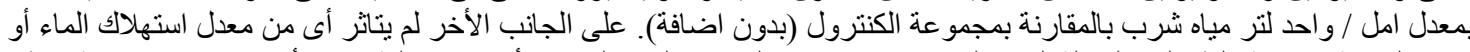

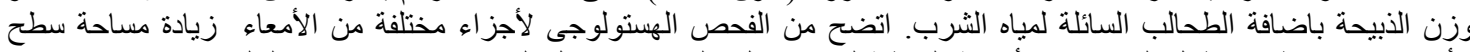

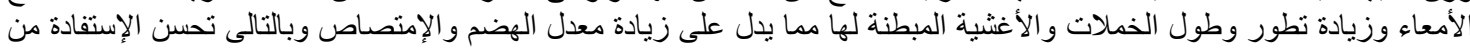
العناصر الغذائية وذلك فى الكتاكيت التى تناولت الطحالب البنية السائلة فى مياه الثرب لبادئ بالمقارنة بالكنترول.

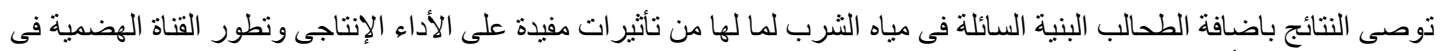

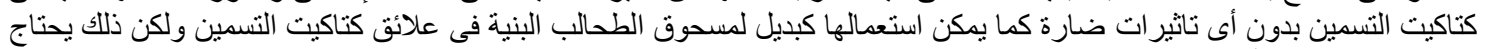

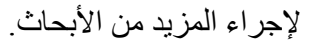

